\title{
La oss diskutere
}

I det siste har jeg truffet mange kolleger fra sykehus ulike steder i Norge. De har samme hjertesukk: Tidligere var det den faglige samtalen og pasientrelaterte spørsmål som preget morgenmøtene og virksomheten for øvrig. Nå er det prioritering og økonomi som dominerer alt fra morgenmøter til lunsjsamtaler. Hvis dette stemmer, er det alvorlig. Men hvorfor er det så få som skriver om det?

I Tidsskriftet ønsker vi debatt om spørsmål av fagpolitisk art og om mer rent faglige problemstillinger. Jeg har i to år nå hatt ansvar for spalten Brev til redaktøren, og min erfaring er at leger ikke er så glad i å debattere, med mindre det gjelder saker som direkte angår dem eller når deres egen forskning blir kritisert. Hva verre er - vi involverer oss i forsvinnende liten grad i samfunnsaktuelle debatter der vi burde være sentrale aktører. Hvor er for eksempel den faglige debatten om sykefraværet blitt av? Mange har følt seg kallet til å delta, bare ikke legene.

Som oppmerksomme lesere har fått med seg, har det vært en omlegging av debattstoffet $\mathrm{i}$ Tidsskriftet etter nyttår. Ledere og debattinnlegg samles nå foran i bladet, og denne prominente plassen er ikke tilfeldig (1). Redaksjonen ønsker å synliggjøre viktigheten av meningsbrytning, kontroverser og diskusjon. Forskning er ikke bare undersøkelser, det er like mye diskusjoner omkring og tolking av de funn man gjør. Vi tror norsk medisin trenger debatt på et mer faglig nivå enn det dagspressen kan tilby - om hva som er god forskning, diagnostikk eller behandling og om hva som er god helsepolitikk og helseforvaltning. Helsevesenet, helsevesenets praktikere og pasientene er tjent med at også spørsmål som angår prioritering, lovverk og organisering av helsetjenestene blir gjenstand for debatt. Ett eksempel: Samhandlingsreformen, som ble lagt frem sommeren 2009, er godt kjent av de fleste. Den er også en av de mest omfattende helsereformer i nyere tid. Men hvor blir det av debatten? Med noen få unntak er den omtrent fraværende. Høringsrunden vil kanskje få flere på banen, men det er langt fra sikkert - det var også relativt stille rundt den store sykehusreformen i 2002 .

Hvorfor unnlater leger å engasjere seg i reformer som kan ha dyptvirkende konsekvenser for deres egen praksis? Det er neppe fordi vi leger mener at våre synspunkter ikke er viktige i disse sakene. Likevel deltar vi altså i forbausende liten grad. Skyldes det mangel på tid? Føler vi oss usikre som samfunnsdebattanter? Mener vi at enkelte saker ikke bør debatteres offentlig, men helst tas på kammerset (2)? Eller er det misforstått lojalitet overfor kolleger som gjør at uenighet ikke flagges i offentligheten? Er leger konfliktvegrende og konsensusorienterte? Det er neppe karrierefremmende å bli oppfattet som kranglefant og polemiker. Det er imidlertid et demokratisk problem hvis grunnen til at man lar være å ytre seg kritisk, er frykt for at ledelsen vil reagere (3).

Uenighet, avvik, konflikt og strid er viktigere enn noen gang. Vi lever i et samfunn med høyt tempo og økende krav til konformitet (4). I kampen om å få hverdagen til å gå opp er det mange som ikke tar seg tid til å delta i det offentlige ordskiftet. Det er nok også fremdeles slik at medisinerutdanningen er mer preget av innlæring av ferdigheter og kunnskaper enn av oppøving av evnen til kritisk refleksjon og fagkritikk. Men sann innsikt nås bare gjennom meningsutveksling der fremsatte påstander kan korrigeres i konfrontasjon med andre meninger. Uten at vi kjenner motargumentene, kan vi ikke vite om vi har rett. Meningsbrytning gjør også at personlige idiosynkrasier og økonomiske interesser lettere blir erkjent. Det vil alltid være noen stemmer som bevisst eller ubevisst ønsker å lukke debatten. Vårt ønske er altså å bidra til å holde den åpen og la så mange stemmer som mulig komme til orde om sentrale spørsmål i det medisinske felt.

Det er ofte de samme legene som stadig ytrer seg om medisin og helse i mediene. Hvordan skal vi få flere i tale? Mange blir nok maktesløse fordi de helse(politiske) sakene er så komplekse at det er krevende å sette seg inn i dem. Men man trenger ikke ha det totale overblikk over en reform, et fagkompleks eller en sak for å kunne ytre seg - det holder som regel at man har forsøkt det man kan. En spissformulert kommentar kan være det beste utgangspunkt for en fruktbar debatt. Vi på vår side skal gjøre vårt for å slippe ulike synspunkter til, og vi kan også bistå med hjelp til utformingen. Mens refusjonsraten er økende for det vitenskapelige stoffet i Tidsskriftet, vil vi fortsatt ha lav terskel for innlegg til debattspaltene. Grunnen er enkel, men vesentlig: Åpenhet og kritikk er noe av det viktigste ved det moderne demokrati (5).

Kommentarspalten er nå åpnet for innspill av ulik karakter og lengde én spalte, to spalter eller en hel trykkside. Korte debattinnlegg vil altså ikke lenger bli plassert i spalten Brev til redaktøren, de vil få plass i kommentarspalten. Leserbrevspalten vil på sin side bli rendyrket som debattforum om artikler som har stått på trykk i Tidsskriftet.

Vi håper det står bedre til med den faglige samtalen ved norske sykehus enn det ryktet skulle tilsi. Hvis dette ikke er tilfellet, tilbyr Tidsskriftet herved spalteplass til samtalen som er uteblitt, i tillegg til at vi utfordrer til meningsutveksling om hvorfor det er blitt slik og hva som kan gjøres for å rehabilitere diskusjonen. Hvis vi skal ha en levende spalte, er vi helt avhengig av spontant innsendt stoff om denne og andre saker. Redaksjonen vil fortløpende vurdere om vi bør spille en mer aktiv rolle og i større grad gå ut og innhente debattinnlegg. Men først og fremst håper vi altså dere vil ta utfordringen og hjelpe oss med å heve både kvantiteten og kvaliteten på debattstoffet i Tidsskriftet ved selv å bidra.

\section{Anne Kveim Lie}

ahlie@medisin.uio.no

Anne Kveim Lie (f. 1969) er postdoktor ved Institutt for helse og samfunn ved Universitetet i Oslo og medisinsk redaktør i Tidsskriftet.

\footnotetext{
Litteratur

. Haug C. Ingen fremgang uten meningsbrytning. Tidsskr Nor Legeforen 2010; 130: 11.

. Haug C. « ... og diskusjoner øker frykten». Tidsskr Nor Legeforen 2009: 129: 2469.

. Aasland OG, Førde R. Legers faglige ytringsfrihet. Tidsskr Nor Legeforen 2008 128: $1838-40$

4. Åmås KO. Verdien av uenighet. Debatt og dissidens i Norge. Oslo: Kagge forlag, 2007.

5. Norges offentlige utredninger. «ydringsfrihed $b ø r$ finde sted». Ytringsfrihetskommisjonens forslag til ny grunnlov $\S 100$. NOU 1999: 27. www.regjeringen.no/ $\mathrm{nb} / \mathrm{dep} / \mathrm{jd} / \mathrm{dok} /$ nouer/1999/nou-1999-27.html?id=142119 (21.2.2010).
} 